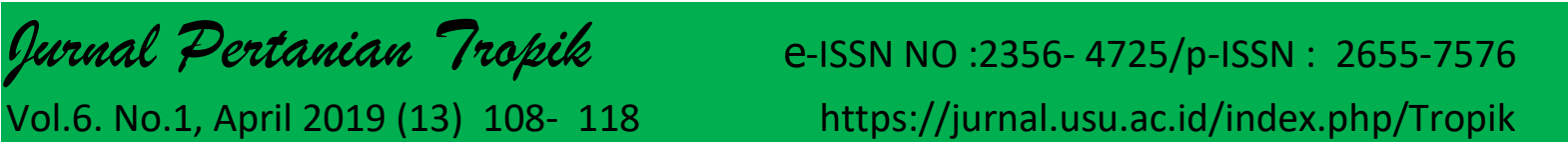

\title{
Pengaruh Aplikasi Kitosan Antifungi Untuk Pengendalian Penyakit Antraknosa Pada Cabai
}

Influence application of chitosan formula for controlling anthracnose disease

\author{
Yadi Suryadi *, Dwiningsih Susilowati, I Made Samudra dan Tri Puji Priyatno \\ Balai Besar Biogen J1 Tentara Pelajar 3A Bogor 16111 \\ *corresponding author email: yshid@yahoo.co.uk
}

\begin{abstract}
Anthracnose (Colletotrichum spp.) may causing low fruit production on both quantity and quality. To avoid the use of synthetic pesticides, an alternative control measure that is environmentally friendly including chitosan as an inhibiting agent is needed. The aim of this study is to test the effectiveness of nano chitosan formula to control anthracnose disease through in vivo test on chili plants cv. Tanjung under field condition. The study was conducted at field experiment station of Pacet Cianjur, West Java from May to September 2017, using $R C B D$ consisted of 6 treatments and 5 replications. The Chitosan-tripolyphosphate $(C-T P P)$ nanoparticles formulation was dissolved in water and applied to chili plants with a concentration of 0.5 - $2 \mathrm{~mL} / \mathrm{L}$. Application by spraying formula was carried at 30-65 days old after planting using a knapsack sprayer. Chitosan tends to inhibit the infection of Colletotrichum spp. on chili. At the $5^{\text {th }}$ observation, the chitosan could inhibit anthracnose infection on chili fruit with the disease intensity ranged from 0.41 to $2.41 \%$. The results showed that C-TPP at concentrations of $0.5-1.0 \mathrm{~mL} / \mathrm{L}$ was effective in suppressing anthracnose on chilli fruit, with the degree of inhibition $>50 \%$ compared with that of control treatment (without C-TPP). The results of the study indicated that chitosan can be applied to reduce the rate infection of anthracnose on chili, and further study is still needed to test in other locations and different seasons.
\end{abstract}

Keywords: chili, anthracnose, Colletotrichum spp., chitinase, chitosan, antifungal.

\begin{abstract}
ABSTRAK
Penyakit antraknosa (Colletotrichum spp.) dapat menyebabkan rendahnya kuantitas maupun kualitas buah yang dihasilkan. Untuk menghindari penggunaan pestisida sintetik maka diperlukan alternatif pengendalian yang bersifat ramah lingkungan, diantaranya kitosan sebagai agen penghambat penyakit antraknosa. Tujuan penelitian ini adalah menguji efektifitas formula nano kitosan untuk mengendalikan penyakit antraknosa melalui pengujian in vivo pada tanaman cabai cv. Tanjung di lapangan. Penelitian dilaksanakan di KP Pacet Cianjur, Jawa Barat sejak bulan Mei sampai September 2017, menggunakan RAK terdiri dari 6 perlakuan dan 5 ulangan. Kitosan-tripolifosfat (K-TPP) nanopartikel dilarutkan dalam air dan diaplikasikan pada tanaman cabai dengan konsentrasi $0,5-2 \mathrm{~mL} / \mathrm{L}$. Aplikasi penyemprotan formula dilakukan saat tanaman berumur 30 - 65 hari setelah tanam menggunakan alat semprot punggung. Kitosan cenderung menghambat infeksi fungi Colletotrichum spp. pada cabai. Pada pengamatan ke-5, penghambatan kitosan terhadap buah cabai terinfeksi antraknosa masing-masing berkisar dengan intensitas serangan. 0,41 sampai 2,41\%. Hasil penelitian menunjukkan K-TPP pada konsentrasi 0,5 - 1,0 $\mathrm{mL} / \mathrm{L}$ cukup efektif menekan penyakit antraknosa pada buah cabai, dengan daya hambat $>50 \%$ dibanding perlakuan kontrol (tanpa KTPP). Hasil penelitian mengindikasikan bahwa kitosan bisa diaplikasikan untuk memperlambat
\end{abstract}


laju infeksi penyakit antraknosa pada buah cabai, dan penelitian lanjutan masih diperlukan untuk menguji di lokasi lainnya serta musim yang berbeda.

Kata Kunci : cabai, antraknosa, Colletotrichum spp., kitinase, kitosan, antifungi.

\section{PENDAHULUAN}

\section{Cabai (Capsicum annuum L)} merupakan salah satu komoditas sayuran di Indonesia yang cukup strategis. Luas pertanaman cabai menurut data terakhir sekitar 165000 hektar dan merupakan usaha budidaya yang terluas dibandingkan komoditas sayuran lainnya. Namun, tingkat produktivitas cabai secara nasional selama 5 tahun terakhir sekitar 6 ton/hektar (Kementan, 2015), masih jauh di bawah potensi hasilnya yang berkisar antara 12-20 ton/hektar.

Salah satu penyakit yang sering menimbulkan kerugian pada petani cabai adalah penyakit antraknosa yang disebabkan fungi patogen Colletotrichum spp. Penyakit dapat menurunkan kualitas cabai dan menurunkan minat konsumen (Nayaka et al., 2009). Penyakit memiliki gejala pucuk yang mati dan berlanjut ke bagian bawah tanaman. Daun, ranting, dan cabang menjadi kering berwarna coklat kehitam-hitaman dan buah yang dihasilkan dapat membusuk sebelum dapat dipanen (Herwidyarti et al., 2013).

Pengendalian penyakit antraknosa dengan menggunakan varietas cabai yang tahan adalah paling baik dan ekonomis. Namun demikian saat ini masih sedikit cabai unggul yang tahan penyakit terhadap berbagai strain patogen dan virulensi berbeda dari satu tempat ke tempat yang lain. Pada umumnya pengendalian kimiawi sangat efektif, namun beberapa laporan menunjukkan patogen menjadi resisten dan masalah residu menjadi isu pada lingkungan dan perdagangan bebas.

Berdasarkan hal tersebut, saat ini dibutuhkan alternatif lain yang dapat diaplikasikan secara aman dalam mengendalikan penyakit antraknosa pada cabai diantaranya dengan menggunakan kitosan sebagai pelapis buah (Hamdayanty et al., 2012). Kitosan dilaporkan dapat menginduksi respons ketahanan tanaman terhadap infeksi patogen (Hadrami et al., 2010). Potensi kitosan sangat luas dapat mengendalikan berbagai patogen tanaman seperti Fusarium solani f. sp. glycines (Prapagdee et al., 2007), Botrytis cinerea and Penicillium expansum (Liu et al., 2007), Colletotrichum sp. (Munoz et al., 2009), Rhizopus stolonifer (Garcia-Rincon et al., 2010), Alternaria kikuchiana and Physalospora piricola (Meng et al., 2010), dan A. alternata (Sanchez-Dominguez et al., 2011). Kitosan mampu menghambat pertumbuhan Colletotrichum musae melalui penghambatan perkecambahan konidium, memperkecil lebar hifa, memperpendek ruas hifa, dan menyebabkan hifa lisis (Pamekas, 2009).

Kitosan yang dilarutkan dalam asam lemah sangat terbatas untuk aplikasi di lapangan. Hasil kajian dilaporkan pelapisan benih tanaman artichoke dengan kitosan masih tidak berbeda dibandingkan dengan tanaman tanpa pelapisan kitosan terhadap infeksi patogen Rhizopus sp. (Ziani et al., 2010). Bautista-Banos et al. (2003) juga melaporkan buah papaya yang dilapisi kitosan patogen Phomopsis sp. masih sering bisa diisolasi dari buah. Perlakuan benih terinfeksi Colletotrichum sp. dengan kitosan masih kurang efektif dibandingkan perlakuan pada benih bebas infeksi (Photchanachai et al., 2006). Hal tersebut menunjukkan keterbatasan efek polimer kitosan. Oleh karena itu, kitosan yang akan digunakan perlu dilakukan modifikasi diantaranya menggunakan enzim kitinase untuk mendapatkan kitosan dengan bobot molekul rendah. Modifikasi fisik pada kitosan mencakup perubahan ukuran partikel menjadi lebih kecil untuk pemanfaatan yang lebih luas yang mengarah ke bentuk nanopartikel. Nanopartikel mempunyai keunggulan 
dibandingkan dengan material sejenis dalam ukuran besar (bulk) karena ukuran partikel memiliki nilai nisbah antara luas permukaan dan volume yang lebih besar, sehingga nanopartikel bersifat lebih reaktif (Chattopadhyay \& Inamdar, 2012).

Kitosan nanopartikel saat ini banyak digunakan di bidang pertanian dengan potensi meningkatkan kualitas benih seperti perkecambahan dan vigor, serta bertindak sebagai biostimulan tanaman terhadap perkembangan sel reticular dan derajat lignifikasi (Martinez, 2002). Disamping itu, kitosan nanopartikel juga bisa diaplikasikan sebagai antimikroba. Qi et al., (2004) melaporkan kitosan nanopartikel dapat menghambat pertumbuhan bakteri Escherichia coli, Salmonella choleraesuis, S. typhimurium, dan S.aureus karena terjadinya gangguan pada membran sel dan kebocoran sitoplasma.

Sejauh mana pengaruh penambahan nanopartikel kitosan sebagai bahan pelindung yang efektif untuk menghambat infeksi fungi $C$. gloeosporioides pada buah perlu dikaji lebih lanjut untuk mengkaji efektifitasnya. Penelitian bertujuan menguji daya hambat kitosan hasil modifikasi secara enzimatik oleh enzim kitinolitik yang dihasilkan isolat bakteri terhadap penyakit antraknosa pada cabai melalui evaluasi pengujian in vitro dan in vivo. Penelitian ini diharapkan dapat memberikan kontribusi mengenai potensi penggunaan kitosan nanopartikel sebagai agen antifungi untuk mengurangi serangan penyakit antraknosa (C.gloeosporioide) pada buah cabai.

\section{BAHAN DAN METODE}

\section{Penyiapan Bakteri Kitinolitik, Kitosan Bobot Molekul Rendah (K-BMR) dan Kitosan-tripolifosfat (K-TPP),}

Bakteri penghasil kitinase diperbanyak dengan cara pengenceran seri bertingkat $\left(10^{-1}\right.$ hingga $\left.10^{-7}\right)$. Sampel dari pengenceran seri dipindahkan ke media nutrient agar (NA) dengan metode pour plate (cawan tuang) dan diinkubasi pada suhu ruang dan waktu 2 sampai 3 hari, kemudian dilakukan metode cawan gores kuadran. Penyimpanan bakteri dilakukan pada media agar miring yang berisikan media nutrient agar (NA) yang ditempatkan di tabung reaksi bertutupkan kapas. Isolat bakteri dari Lembang (isolat TBG) diremajakan pada media agar miring (kaldu nutrient) yang disterilisasi pada suhu $121^{\circ} \mathrm{C}$ selama 15 menit. Isolat bakteri diinokulasikan pada media agar dengan cara sebanyak 1 ose bakteri digoreskan pada media kaldu nutrien (Prima et al., 2015).

K-BMR dibuat dengan cara, melarutkan $2 \mathrm{~g}$ kitosan (bobot molekul 600 $\mathrm{kDa}$ ), dalam $100 \mathrm{~mL}$ larutan asam asetat 1\%. $\mathrm{pH}$ 3.5. Campuran tersebut diaduk menggunakan pengaduk magnetik pada alat pengocok orbital (IKA K-260) dengan kecepatan $75 \mathrm{rpm}$ selama 24 jam hingga kitosan larut sempurna. Larutan kitosan diatur pHnya menjadi 5.3 dengan penambahan $\mathrm{NaOH}$. Larutan kitosan sebanyak $20 \mathrm{~mL}$ dihidrolisis menggunakan $0.2 \mathrm{~mL}$ enzim kitinase (hasil ekstraksi isolat bakteri TBG) pada suhu $37^{\circ} \mathrm{C}$ serta waktu inkubasi selama 24 jam (Kumar et al., 2006). Proses hidrolisis dihentikan dengan pemanasan $100^{\circ} \mathrm{C}$ selama 5-10 menit. Kitosan hasil hidrolisis dipresipitasi (endapan putih) menggunakan sentrifugasi (Hettich d-78532), dengan kecepatan $10.000 \mathrm{rpm}$ selama 10 menit, pelet dicuci dengan air destilasi hingga $\mathrm{pH}$ netral. Endapan pelet tersebut merupakan kitosan bobot molekul (BM) rendah yang kemudian disimpan dalam freezer bersuhu $4^{\circ} \mathrm{C}$ sebelum dilakukan pengujian selanjutnya (Handayani et al., 2013; Nadia et al., 2014). Pengukuran K-BMR hasil hidrolisis isolat TBG dilakukan menggunakan alat Viskometer Ostwald dengan pelarut asam asetat $1 \%$.

Kitosan nanopartikel disiapkan dengan metode metode gelasi ionik modifikasi Qi et al., (2004). Kitosan (BM 
$600 \mathrm{kDa}$; derajat deasetilasi 95\%) dilarutkan menjadi $0.5 \% \mathrm{w} / \mathrm{v}$ dalam asam asetat $1 \% \mathrm{v} / \mathrm{v} \mathrm{pH}$ 4.6-4.8 dengan $10 \mathrm{~N}$ $\mathrm{NaOH}$. Kitosan nanopartikel akan terbentuk secara spontan dengan penambahan $1 \mathrm{ml}$ larutan tripolifosfat (TPP) $(0.1-0.25 \%, w / v)$ dalam $3 \mathrm{~mL}$ larutan kitosan pada kondisi pengadukan (waktu perlakuan pengadukan selama 60 menit) menggunakan magnetic stirring pada suhu ruang. Nanopartikel disentrifugasi pada kecepatan $9000 \times g$ selama 30 min. Supernatant dibuang dan Kitosan nanopartikel dicuci dengan air destilasi. Larutan tersebut ditambahkan $0.25 \mathrm{~mL}$ larutan tween $80 \quad 0.2 \%$ secara perlahan dengan tetap diaduk hingga 30 menit. Perbandingan volume antara larutan K-BMR $0.2 \%$ : NaTPP $0.1 \%$ adalah $5: 2$ (v/v). Pengadukan terus dilanjutkan sampai satu jam kemudian larutan disimpan dalam freezer hingga dilakukan uji selanjutnya. Suspensi K-TPP disimpan dalam lemari pendingin dengan suhu $4^{\circ} \mathrm{C}$ sebelum dilakukan pengujian (Chattopadhyay \& Inamdar 2012).

\section{Percobaan di lapang}

Percobaan efikasi kitosan terhadap antraknosa dilaksanakan di kebun percobaan (KP) Pacet, Cianjur (BB Biogen, Bogor, Jawa Barat) sejak bulan Mei sampai dengan September 2017. Lahan tersebut sebelumnya ditanami tanaman dengan pola rotasi tanaman ubi-jagung-pakcoy-cabai. Varietas cabai merah yang digunakan adalah varietas Tanjung. Bibit cabai berumur 21 hari setelah sebar ditanam satu bibit per lubang dengan jarak tanam $60 \mathrm{~cm}$ x $70 \mathrm{~cm}$ pada petak-petak percobaan berukuran $5 \mathrm{~m}$ x $5 \mathrm{~m}^{2}$.

Pemeliharaan tanaman dilakukan dengan pemberian pupuk kandang (kotoran kambing) sebanyak 8-10 ton/ha dan pupuk ZA $50 \mathrm{~kg}$ dan TSP $50 \mathrm{~kg}$ per hektar. Pupuk urea $1 / 3$ bagian diberikan saat tanam dan $1 / 3$ bagian diberikan lagi saat 2 dan 4 minggu setelah tanam. Percobaan dilaksanakan dalam rancangan acak kelompok (RAK) dengan 6 perlakuan dan 5 ulangan (Tabel 1). Aplikasi K-TPP (nanokitosan) dilakukan dengan interval 7 hari sekali dilakukan sejak umur 30 hari setelah tanam (hst), 37, 44, 51, 58 dan 65 hst. Aplikasi dilakukan menggunakan alat semprot punggung semi otomatis dengan volume semprot setara $600-700 \mathrm{~L} / \mathrm{ha}$.

Tabel 1. Susunan perlakuan K-TPP untuk uji efikasi di lapangan

\begin{tabular}{lll}
\hline No. & Perlakuan & $\begin{array}{l}\text { Konsentrasi } \\
(\mathrm{mL} / \mathrm{L})\end{array}$ \\
\hline 1 & K-TPP & 0,5 \\
2 & K-TPP & 1,0 \\
3 & K-TPP & 1,5 \\
4 & K-TPP & 2,0 \\
5 & Kontrol (tanpa K-TPP) & - \\
6 & Kontrol fungisida pembanding (Antracol) & $2 \mathrm{~g} / 1$ \\
\hline
\end{tabular}


Pengamatan penyakit dilakukan sehari menjelang aplikasi pada 10 tanaman contoh per petak. Variabel data penyakit antraknosa ( $C$. gloeosporioides) dihitung dengan persamaan:

dimana:

$$
I=\frac{a}{a+b} \times 100 \%
$$

$\mathrm{I}=$ intensitas serangan, $\mathrm{a}=$ buah terserang,

$\mathrm{b}=$ buah tidak terserang

Kurva perkembangan penyakit antraknosa pada cabai AUDPC dihitung berdasarkan formula (Simko \& Piepho, 2012):

$A U D P C=\sum_{i=1}^{N i-1}(t i-1-t i)\left(\frac{Y i+Y 1+1}{2}\right)$

dimana $Y_{i}=$ intensitas serangan penyakit (persentase) pada pengamatan $\mathrm{ke} i, t_{i}$ $=$ waktu (hari) pada pengamatan ke $i$, dan $\mathrm{N}$ jumlah total pengamatan

Hasil pengamatan pada perlakuan KTPP kemudian dibandingkan dengan kontrol (tanpa perlakuan). Tingkat efektifitas untuk menentukan keefektifan K-TPP yang diuji ditentukan berdasarkan nilai efektifitas pengamatan terakhir. Daya hambat dihitung dengan rumus

$$
D H=\frac{\mathrm{IK}-\mathrm{IP}}{\mathrm{IK}} \times 100 \%
$$

dimana $\mathrm{IK}=$ intensitas pada kontrol; $\mathrm{IP}=$ intensitas pada perlakuan.

Sebagai data pendukung diamati produksi buah cabai (gr/pohon). Data dianalisis dengan analysis of variance (ANOVA), Keragaman dan perbedaan ratarata antar perlakuan dianalisis dengan menggunakan Program Sirichai ver. 6.1.

\section{HASIL DAN PEMBAHASAN}

Formulasi kitosan dengan gelasi ionik menggunakan Natrium Tripolifosfat (KTPP)

Untuk mendapatkan kitosan bobot molekul rendah (K-BMR) proses hidrolisis dilakukan pada suhu yang konstan. Pemecahan dengan waktu hidrolisis yang lama akan menyebabkan ikatan-ikatan tersebut kembali menyatu dengan meningkatnya nilai viskositas dan bobot molekul. Kitosan yang digunakan untuk merubah bobot molekulnya menjadi rendah yaitu kitosan yang memiliki kisaran sebesar 100-600 KDa. Hasil pengukuran bobot molekul (BM) K-BMR dengan Viskometer Ostwald menunjukkan nilai BM yang juga rendah yaitu sebesar 48,244 kDa.

Pellet K-BMR dibuat dengan konsentrasi $0.2 \%$ dilarutkan dalam asam asetat $0.1 \%$. kemudian dicampurkan dengan larutan NaTPP $0.1 \%$. Tripolifosfat (TPP) dipilih sebagai pengikat silang karena TPP memiliki lebih banyak muatan negatif sehingga dapat berinteraksi lebih kuat. TPP juga memiliki sifat non toksik sehingga diharapkan tidak akan mengubah biokompatibilitas kitosan (Alauhdin \& Widiarti 2014). Larutan TPP diatur pHnya ( $\mathrm{pH}$ 3) hingga dalam kondisi yang asam hanya terdapat ion-ion tripolifosfat, sedangkan kitosan akan menghasilkan ionion $\left(-\mathrm{NH}_{3}\right)$ apabila dilarutkan dalam asam. Selain itu, pada $\mathrm{pH}$ asam ionisasi amina dari kitosan akan meningkat sehingga semakin besar potensi terbentuknya ikatan antara kitosan dengan TPP. Interaksi ionik yang terjadi antara gugus amina pada kitosan yang bermuatan positif dengan polianion (NaTPP) yang bermuatan negatif membentuk struktur jaringan dalam intermolekul atau intramolekul tiga dimensi (Anggasari, 2013). Pembuatan nano partikel yang digunakan di lapangan adalah perbandingan antara K-BMR : NaTPP (5:2). Formula ini digunakan berdasarkan hasil pengujian sebelumnya pada aktivitas formula K-TPP secara in vivo terhadap fungi Colletotrichum spp. pada buah mangga di laboratorium (Suryadi et al., 2017).

\section{Efikasi K-TPP di lapangan}

C. gloeosporioides merupakan fungi yang bersifat kosmopolitan, sehingga menyebabkan timbulnya penyakit pada ber bagai jenis tanaman. Selain itu, fungi $C$. gloeosporioides juga menyerang batang, daun, dan bunga. Gejala antraknosa pada 
daun berupa bercak tidak teratur, coklat keabuan dan ukurannya tidak lebih dari 5 $\mathrm{mm}$, namun jika sudah banyak, bercak itu akan mengumpul dan menjadi bercak besar dan akhirnya akan membentuk lubang dan daun akan kering kemudian gugur. Gejala pada batang muda berupa bercak coklat keabuan, bisa membesar membentuk gelang melingkar batang dan akhirnya membuat mati bagian yang diserang.

Serangan pada buah terlihat bercak hitam pada kulit dan menyebabkan daging buah di bawahnya menjadi busuk. Perkecambahan spora dapat terjadi pada kelembaban relatif $90 \%$ dengan suhu 15$35^{\circ} \mathrm{C}$, walaupun kelembaban relatif optimum untuk perkecambahan spora fungi ini $90 \%$. Spora C. gloeosporioides juga dapat bertahan pada suhu $>35^{\circ} \mathrm{C}$. Kondisi tanaman yang kekurangan unsur hara, kurang pemeliharaan, suhu udara 29$30^{\circ} \mathrm{C}$ dan kelembaban udara yang tinggi (lebih dari 95\%), akan memudahkan fungi berkembang dengan cepat dan men ginfeksi tumbuhan sehingga menimbulkan kerusakan penyakit yang parah. Pada saat pengujian dilakukan curah hujan relatif rendah dan temperatur cukup tinggi karena memasuki musim kemarau.

\section{Pengaruh K-TPP terhadap intensitas penyakit antraknosa}

Tabel 2. Pengaruh K-TPP terhadap intensitas serangan penyakit antraknosa ( $C$. gloeosporioides) pada tanaman cabai

\begin{tabular}{|c|c|c|c|c|c|}
\hline \multirow{2}{*}{$\begin{array}{l}\text { Perlakuan } \\
(\mathrm{mL} / \mathrm{L})\end{array}$} & \multicolumn{5}{|c|}{ Rerata intensitas penyakit antraknosa (\%) } \\
\hline & $\begin{array}{l}\text { pengamat } \\
\text { an ke } 1^{\text {ns }}\end{array}$ & $\begin{array}{l}\text { pengamata } \\
\text { n ke } 2^{\text {ns }}\end{array}$ & $\begin{array}{l}\text { pengamatan } \\
\text { ke } 3^{\text {ns }}\end{array}$ & $\begin{array}{l}\text { pengamatan } \\
\text { ke } 4^{\text {ns }}\end{array}$ & $\begin{array}{l}\text { pengamatan } \\
\text { ke } 5\end{array}$ \\
\hline K-TPP 0,5 & 0,125 & 0,27 & 0,11 & 0,61 & $0,87 \mathrm{a}$ \\
\hline K-TPP 1,0 & 0,04 & 0,15 & 0,37 & 0,43 & $0,84 \mathrm{a}$ \\
\hline K-TPP 1,5 & 0,29 & 0,86 & 1,4 & 1,75 & $2,14 \mathrm{~b}$ \\
\hline K-TPP 2,0 & 0,41 & 0,94 & 0,79 & 1,89 & $2,06 a b$ \\
\hline $\begin{array}{l}\text { Kontrol (tanpa K- } \\
\text { TPP) }\end{array}$ & 0,30 & 0,62 & 1,02 & 1,12 & $1,80 \mathrm{a}$ \\
\hline Kontrol fungisida 2,0 & 0,12 & 0,29 & 0,97 & 0,21 & $0,41 \mathrm{a}$ \\
\hline
\end{tabular}


Berdasarkan hasil pengamatan ke 3, nampak perlakuan K-TPP konsentrasi 0,5 dan $1,0 \mathrm{~mL} / \mathrm{L}$ nilai penghambatannya di atas 50\%, artinya perlakuan kitosan tersebut cukup efektif menekan penyakit antraknosa (C. gloeosporioides) pada tanaman cabai. Data perkembangan penyakit antraknosa pada pengamatan ke 3 mempunyai kisaran intensitas serangan sebesar 0.11 sampai $1,4 \%$. Nampak terlihat penurunan intensitas penyakit pada perlakuan K-TPP $0,5 \quad-\quad 1,0 \mathrm{~mL} / \mathrm{L}$, ditunjukkan dengan kisaran daya hambat penyakit antraknosa sebesar $63-87 \%$ dibanding perlakuan kontrol (tanpa aplikasi K-TPP). Pada pengamatan ke 4, perlakuan K-TPP 0,5- 1,0 ml/1 masih cukup efektif menekan penyakit antraknosa pada cabai, masing-masing dengan dengan daya hambat 51 dan $69 \%$, sementara fungisida pembanding mempunyai daya hambat $91 \%$.
Pada pengamatan ke 5 daya hambat perlakuan K-TPP $0,5-1,0 \mathrm{~mL} / \mathrm{L}$ masing masing sebesar 51,66 dan 53,33\% masih cukup efektif dibandingkan perlakuan kontrol (tanpa K-TPP), sementara perlakuan fungisida mempunyai daya hambat sebesar 77,22\% (Tabel2) .

Dari grafik perkembangan intensitas serangan penyakit antraknos (Gambar 2), menunjukkan ada perbedaan perkembangan keparahan penyakit di lapangan akibat perlakuan aplikasi K-TPP pada tanaman cabai. Hal serupa dilaporkan bahwa bila benih tanaman diaplikasi kitosan terlebih dahulu dapat menekan infeksi penyakit benih dibandingkan kontrol pada tanaman cabai (Photchanachai et al., 2008), cabai manis (sweet pepper) (Jitareerat et al., 2010), dan gandum (Reddy et al., 1999).

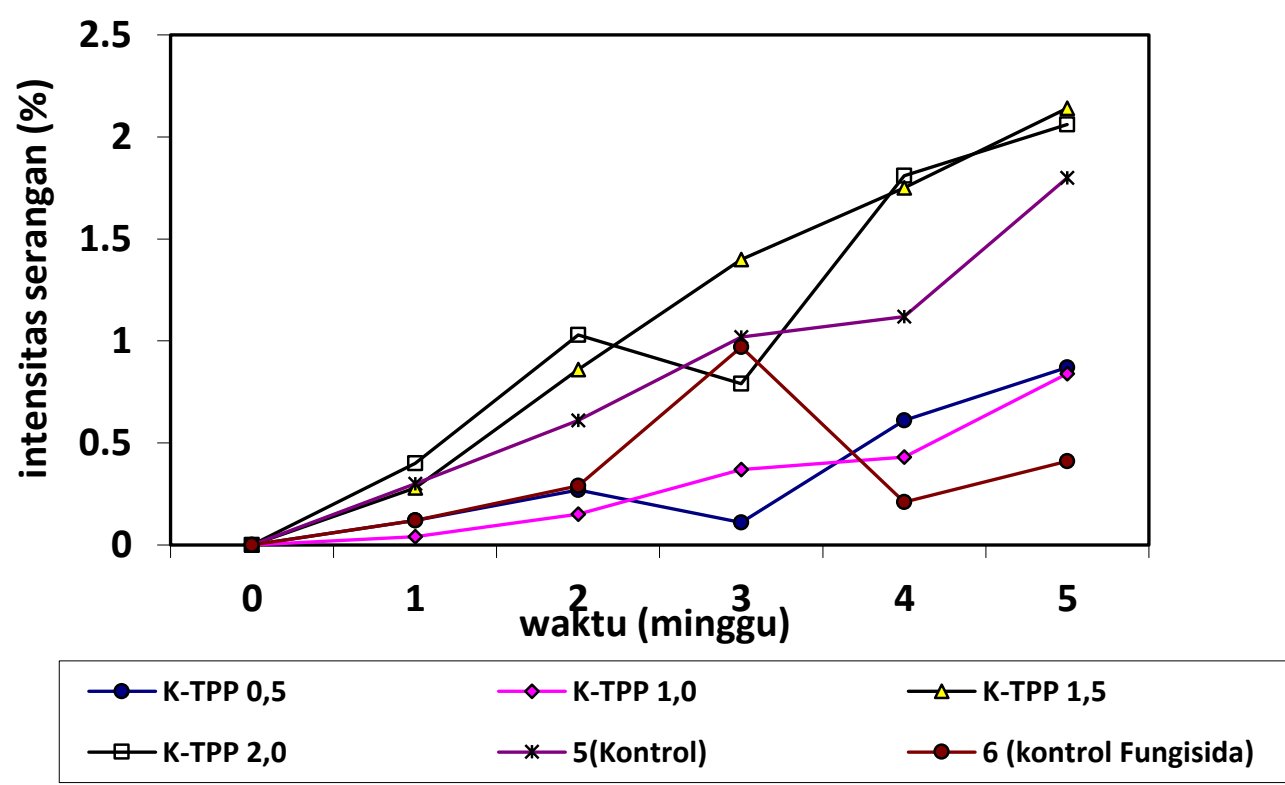

Gambar. 2. Grafik perkembangan intensitas serangan penyakit antraknosa (C. Gloeosporioides) pada tanaman cabai yang diaplikasi K-TPP dan diamati setiap minggu sampai menjelang panen. KP Pacet MT 2017. 


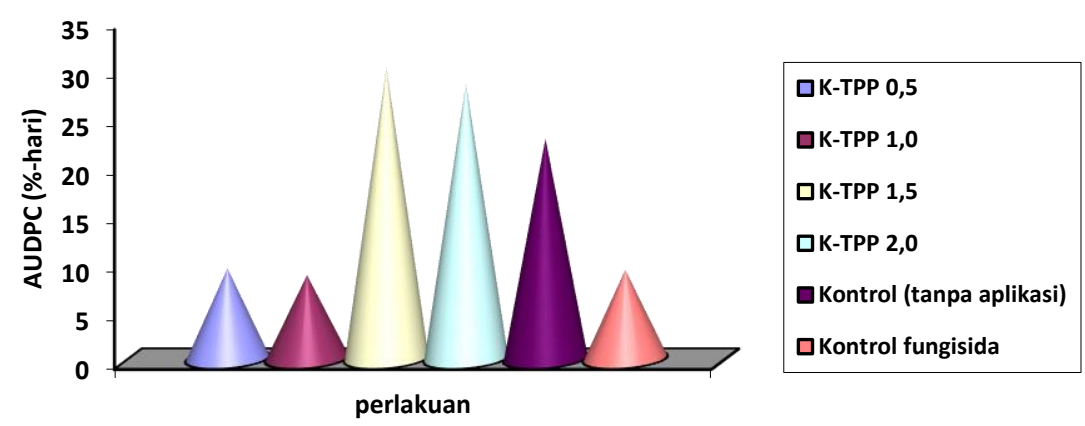

Gambar. 3. Kurva perkembangan penyakit antraknosa (AUDPC) pada cabai.

Hasil analisis terhadap perkembangan intensitas penyakit yang diukur berdasarkan nilai AUDPC menunjukkan nilai AUDPC perlakuan KTPP $0,5-1,0 \%$ cenderung menekan laju perkembangan penyakit dengan daya hambat 65-68\%, sementara perlakuan kontrol fungisida menunjukkan daya hambat 45\% (gambar 3). Perlakuan K-TPP $1,5 \quad-2,0 \%$ kurang efektif dalam menghambat antraknosa.

Hal tersebut menguatkan hasil pengamatan bahwa ada perbedaan daya hambat keparahan penyakit antranosa akibat pemberian formula K-TPP. Menurut Pamekas (2012), kitosan dengan BM rendah sangat efektif dalam menghambat laju respirasi dan kadar etilen buah, memperpanjang umur simpan buah, serta menginduksi peningkatan kadar senyawa fenol total dan kadar protein kasar total buah. Kitosan sebagai pelapis pada permukaan buah dapat menghambat proses respirasi pada tingkat yang sangat rendah. Respirasi rendah dapat mengakibatkan pemecahan pati termasuk gula berjalan lambat sehingga semakin rendah respirasi buah maka proses kematangan buah semakin lambat (Hamdayanty et al., 2012). Kitosan yang diaplikasikan sebagai suspensi untuk penyemprotan tanaman, diduga dapat menunda proses infeksi patogen pada buah. Dengan adanya sifat menghambat pertumbuhan tersebut, maka K-TPP dapat dimanfaatkan sebagai agen antifungi $C$. gloesporioides pada buah cabai.
Penggunaan pestisida sintetik untuk melapisi buah dapat mengakibatkan resiko kesehatan pada konsumen. Untuk menghindari penggunaan pestisida sintetik maka digunakan alternatif pengendalian penyakit antraknosa dengan menggunakan kitosan sebagai pelapis buah yang bersifat ramah lingkungan (Bautista-Banos et al., 2003). Pelarutan kitosan dalam asam dapat mempermudah proses kelarutannya hingga menjadi gel kitosan.

Kitosan yang dilarutkan dalam asam dan air akan mempunyai keunikan membentuk gel yang bersifat stabil dan mempunyai muatan dwi kutub, yaitu muatan negatif pada gugus karboksilat ($\mathrm{OH})$ dan muatan positif pada gugus $\left(-\mathrm{NH}_{3}\right)$. Jika kitosan dilihat dari gugus asam amino dalam bentuk asetil amino $\left(\mathrm{HCONH}_{3}\right)$ dan glukosamin $\left(\mathrm{C}_{6} \mathrm{H}_{9} \mathrm{NH}_{2}\right)$ dalam kitosan yang bermuatan positif dapat berikatan dengan bagian makromolekul pada fungi yang bermuatan negatif. Fungi Colletotrichum spp. yang bersifat negatif akan terhambat oleh kitosan yang bersifat positif. Pertumbuhan fungi terhambat karena bagian apresorium (ujung hifa atau tabung kecambah) akan membengkak sehingga tidak dapat menempel dan mempenetrasi inang (Sitorus et al., 2014). Dari grafik perkembangan penyakit, perlakuan konsentrasi kitosan yang optimal $(0,5-1,0$ $\mathrm{mL} / \mathrm{L}$ ) dalam penyemprotan tanaman cabai menyebabkan infeksi fungi cenderung menurun. Pertumbuhan fungi terhambat karena kemampuan kitosan yang bersifat sebagai anti fungi. 


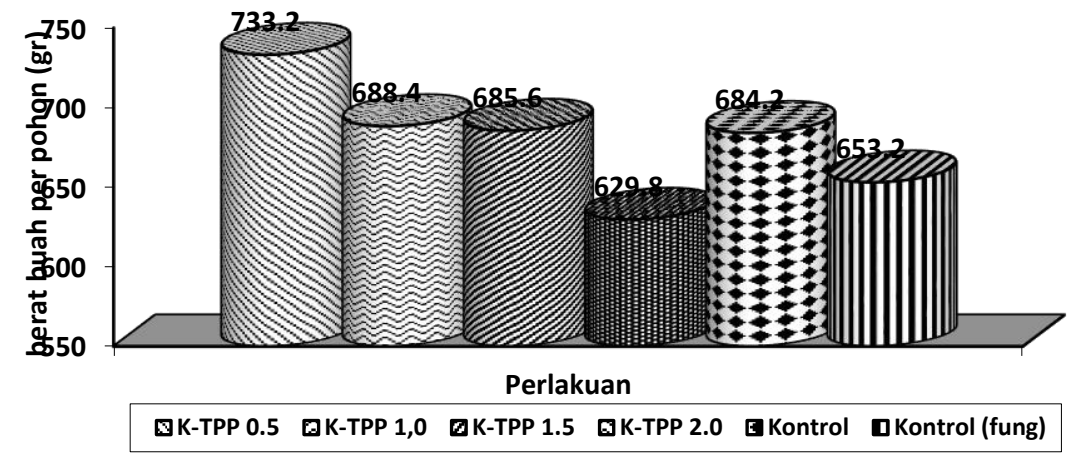

Gambar. 4. Pengaruh aplikasi K-TPP terhadap hasil panen buah cabai. KP Pacet MT 2017.

Kitosan mampu merusak dinding sel fungi yang umumnya tersusun atas lapisan peptidoglikan dan lipopolisakarida (lemak dan protein) (Trisnawati et al., 2013).

\section{Pengaruh K-TPP terhadap hasil panen buah cabai}

Hasil panen buah cabai (berat buah per pohon) dilakukan dari tujuah kali masa petik, Data hasil panen buah cabai total disajikan pada gambar 4. Dari gambar terlihat perbedaan antar perlakuan akibat perlakuan K-TPP dengan kisaran hasil $629,8-733,2 \mathrm{gr} /$ pohon.

\section{SIMPULAN}

K-TPP $0,5-1,0 \mathrm{~mL} / \mathrm{L}$ mampu mengendalikan penyakit antraknosa pada tanaman cabai, dan berpengaruh pada hasil panen cabai di lapangan. Pada penelitian ini aplikasi K-TPP masih dalam skala terbatas dan belum diproduksi skala luas. Perlu dilakukan penelitian lanjutan untuk menguji efektifitasnya terhadap fungi pasca panen lainnya, serta uji parameterparameter lainnya untuk lebih menjamin bahwa kitosan nanopartikel yang akan diaplikasikan di lapangan dapat diproduksi secara masal.

\section{UCAPAN TERIMA KASIH}

Disampaikan terima kasih kepada Sdr Ilyas (Kepala Kebun Percobaan Pacet, Cianjur) atas penyediaan fasilitas dan kelancaran penelitian di lapangan.

\section{DAFTAR PUSTAKA}

Agrios, G.N. 2005. Plant Pathology. Fifth Edition. Elsevier Academic Press, New York

Alauhdin, M., Widiarti, N. 2014. Sintesis dan modifikasi lapis tipis kitosantripolifosfat. Jurnal MIPA. 37(1):4652.

Anggasari. 2013. Sintesis dan karakterisasi membran kitosan-tripolifosfat sebagai alternatif pengontrol sistem pelepasan obat. Semarang (ID): Universitas Negeri Sebelas Maret.

Bautista-Banos, S., Herndez-Lauzardo, M., Bosquez-Molina, E., Wilson, C.L. 2003. Effects of chitosan and plant extracts on growth of Colletotrichum gloeosporioides, anthracnose levels and quality of papaya fruit. Crop Prot. 22:1087-1092.

Chattopadhyay, D.P., Inamdar, MS. 2012. Studies on synthesis. characterization. and viscosity behaviour of nano chitosan. Research Journal of Engineering Sciences. 1(4):9-15.

Garcia-Rincon, J., Vega-Prez, J., GuerraSanchez, M.G., Hernandez-Lauzardo, 
A.N.,Pena-Diaz, A., Velazquez-Del Valle, M.G. 2010. Effect of chitosan on growth and plasma membrane properties of Rhizopus stolonifer (Ehrenb.:Fr.) Vuill. Pestic.Biochem. Physiol. 97:275-278.

Hadrami, El A., Adam, L.R., Hadrami El I., Daayf, F. 2010. Chitosan in plant protection. Mar Drugs. 8(4):968-987. doi:10.3390/md8040968.

Hamdayanty., Yunita, R., Amin, N.N., Damayanti. T.A. 2012. Pemanfaatan kitosan untuk mengendalikan antraknosa pada pepaya (Collectotrichum gloeosporiodies) dan meningkatkan daya simpan buah. Jurnal Fitopatologi Indonesia. 8(4):97-102.

Herwidyarti, H.K., Ratih, S., Sembodo Jekti, R.D. 2013. Keparahan penyakit antraknosa pada cabai (Capsicum annuum L). Jurnal Agrotek Tropika. 1(1):102-106.

Jitareerat, P., Photochanachai, S. 2010. Application of sodium carbonate and chitosan for controlling anthracnose disease in bell pepper seeds. Agricultural Sci. J. $\quad 41(3 / 1)$ (Suppl.):373-376.

[Kementan] Kementerian Pertanian. 2015. Outlook Komoditas Pertanian Subsektor Hortikultura Cabai. Jakarta (ID): Kementan.

Kumar, A.B.V., Varadaraj, M.C., Gowda, L.R., Tharanathan, R.N. 2006. Low molecular weight chitosan-Preparation with the aid of pronase, characterization and their bactericidal activity towards Bacillus cereus and Escherichia coli. Biochimica et Biophysica Acta. 1770(2007):495-505.

Liu, H., Du, Y., Wang, X. Sun, L. 2004. Chitosan kills bacteria through cell membrane damage. Int. J. Food Microbiol. 95:147-155.

Mardliyati, E., Muttaqien, S., Setyawati, D.R. 2012. Sintesis nanopartikel kitosan-trypolyphosphate dengan metode gelasi ionik pengaruh konsentrasi dan rasio volume terhadap karakteristik partikel. Prosiding Pertemuan Ilmiah Ilmu Pengetahuan dan Teknologi.

Martinez, P.A. 2002. Biological pesticide based on chitosan and entomopathogenic nematodes. Patent: WO/2002/037966.

Meng, X., Yang, L., Kennedy, JF., Tian, S. 2010. Effects of chitosan and oligochitosan on growth of two fungal pathogens and physiological properties in pear fruit. Carbohyd. Polym. 81:7075.

Munoz, Z., Moret, A., Garces, S. 2009. Assessment of chitosan for inhibition of Colletotrichum sp. on tomatoes and grapes. Crop Prot. 28:36-40.

Nadia, L.M.H., Suptijah, P., Ibrahim, B. 2014. Produksi dan karakterisasi nano kitosan dari cangkang udang windu dengan metode gelasi ionic. Jurnal Pengolahan Hasil Perikanan Indonesia. 17(2):119-126.

Nayaka, C.S., Shankar, A.C.U., Niranjana, S.R., Prakash, H.S., Mortensen, C.N. 2009. Anthracnose disease of chilli pepper. Technical Bulletin.

Pamekas, T. 2009. Induksi ketahanan buah pisang ambon curup terhadap penyakit pascapanen antraknos dan penundaan kematangan dengan aplikasi kitosan. Yogyakarta (ID): Fakultas Pertanian, Universitas Gadjah Mada.

Prima, A., Devi, S., Saryono. 2015. Optimalisasi $\mathrm{pH}$ produk enzim selulase dari bakteri endofitik Pseudomonas stutzeri LKBURCC45, Pseudomonas cepacia LKBURCC48, dan Pseudomonas stutzeri LKBURCC59. Jurnal Online Mahasiswa FMIPA.2(1): 199-204.

Photchanachai, S., Singkaew, J. Thumthong, J. 2006. Effect of chitosan seed treatment on Colletotrichum sp. and seedling growth of chilli cv. 'Jinda'. Acta Hort.712:585-590.

Photchanachai, S., Kerdchoechuen, O., Jitareerat, P., Boonchoo, T., Loyma, D. 
2008. Effect of chitosan and hot water treatment on protection of infection of Collectotrichum sp. in chilli seeds. Annual Report, Bangkok.

Prapagdee, B., Kotchadat, K., Kumsopa, A., Visarathanonth, N. 2007. The role of chitosan in protection of soybean from sudden death syndrome caused by Fusarium solani f. sp. glycines). Bioresour. Technol. 98:1353-1358.

Qi, L., Xu, Z., Jiang, X., Hu, C., Zou, X. 2004. Preparation and antibacterial activity of chitosan nanoparticles. Carbo. Res. 339:2693-2700.

Reddy, B.M.V., Arul, J., Angers, P., Couture, L. 1999. Chitosan treatment of wheat seeds induces resistance to Fusarium graminearum and improves seed quality. J. Agric. Food Chem. 47:1208-1216.

Sanchez-Dominguez, D.S., Rios, M.Y., Castillo-Ocampo, P., Zavala-Padilla, G., Ramos-Garcia, M., BautistaBanos, S. 2011. Cytological and biochemical changes induced by chitosan in the pathosystem Alternaria alternata-tomato. Pestic. Biochem. Physiol. 99:250-255.
Simko, I., Piepho, H.P. 2012. The area under the disease progress stairs: Calculation, advantage, and application. Phytopathology 102:381389.

Sitorus, R.F., Karo-Karo, T., Lubis, Z. 2014. Pengaruh konsentrasi kitosan sebagai edible coating dan lama penyimpanan terhadap mutu buah jambu biji merah. Jurnal Teknologi Pangan. 2(1):37-46.

Suryadi, Y, Priyatno, T.P., Samudra, I.M., Susilowati, D.N., Sriharyani, T.S., Syaefudin. 2017. Control of anthracnose disease (Colletotrichum gloeosporioides) using nano chitosan hydrolyzed by chitinase derived from Burkholderia cepacia isolate E76. Jurnal AgroBiogen 13(2):111-122.

Trisnawati, E., Andesti, D., Saleh, A. 2013. Pembuatan kitosan dari limbah cangkang kepiting sebagai bahan pengawet buah duku dengan variasi lama pengawetan. Jurnal Teknik Kimia. 2(19):17-26.

Ziani, K., Beatriz, U., Juan, I.M. 2010. Application of bioactive coatings based on chitosan for artichoke seed protection. Crop Prot. 29:853-859. 